\title{
Double Labeling of Microtubules and Actin Filaments in Maize Leaf Division Zone
}

Qiong Nan ${ }^{1}$, Janette Mendoza ${ }^{2}$ and Michelle Facette ${ }^{1, *}$

\author{
${ }^{1}$ University of Massachusetts, Amherst, USA; ${ }^{2}$ University of New Mexico, New Mexico, USA \\ *For correspondence: mfacette@umass.edu
}

\begin{abstract}
[Abstract] Maize leaves grow in a gradient. The base of young maize leaves contains a high proportion of symmetrically and asymmetrically dividing cells, making the leaf an effective model system for the study of cell division. Here, we describe a double staining method to visualize actin filaments and microtubules in fixed maize leaf tissues, using immunofluorescent staining for microtubules and fluorescent phalloidin staining for actin filaments. This method provides a technique for the study of the cytoskeleton during maize cell division.
\end{abstract}

Keywords: Maize, Actin filament, Microtubules, Double staining, Division zone

[Background] Immature growing maize leaves mature in a gradient. The developing leaf blade, which is distal to the pre-ligular band or ligule, has three primary developmental zones. Proximal to the base or ligule are undifferentiated cells undergoing symmetric divisions, followed by differentiating cells undergoing asymmetric divisions, and finally cells that are no longer dividing but undergoing rapid cell expansion (Sylvester et al., 1996; Facette et al., 2013). This makes the monocot leaf an excellent model for studying cell division and aspects of leaf development. The developmental progression observed in monocot leaves has been used to study photosynthetic and vascular bundle formation in maize (Li et al., 2010); stomatal divisions in Brachypodium distachyon (Raissig et al., 2016), rice (Wu et al., 2019) and maize (Facette et al., 2015); and cell division in maize (Hunter et al., 2012; Nelissen et al., 2012). Maize leaves have large cells excellent for imaging these processes. Live cell imaging of the immature leaf using fluorescent markers is powerful (Rasmussen, 2016), however this requires that plants express transgenic markers, which can be limiting. We present a whole-mount procedure that does not require difficult and time-consuming sectioning, to observe the actin and microtubule cytoskeleton in the developing maize leaf epidermis.

\section{Materials and Reagents}

1. Glass Scintillation vial $(20 \mathrm{ml})$

2. Parafilm

3. Microscope slides

4. Microscope cover slips (use glass coverslips of appropriate thickness for your microscope objective, typically 1.5. Wide cover glasses are convenient, we recommend Fisher 12-544-D)

5. Corning Netwell Inserts and 12-well plate (Corning, catalog number: 3478) 
6. M-maleimidobenzoyl-N-hydroxysuccinimide ester (MBS) (Thermo Fisher, catalog number: 22311)

7. PIPES (Fisher Scientific, catalog number: 50-144-6210)

8. HEPES (Alfa Aesar, catalog number: A1477709)

9. $\mathrm{MgSO}_{4}$ (Fisher Scientific, catalog number: AC423900250)

10. $\mathrm{KOH}$ (Fisher Scientific, catalog number: 18-605-601)

11. $\mathrm{Na}_{2} \mathrm{HPO}_{4} \cdot 7 \mathrm{H}_{2} \mathrm{O}$ (Fisher Scientific, catalog number: 18-606-699)

12. $\mathrm{NaCl}$ (Fisher Scientific, catalog number: 18-606-422)

13. $\mathrm{KCl}$ (Sigma-Aldrich, P5941)

14. $\mathrm{KH}_{2} \mathrm{PO}_{4}$ (Fisher Scientific, catalog number: 18-602-144)

15. Methanol (Fisher Scientific, catalog number: 18-604-352)

16. EGTA (Fisher Scientific, catalog number: O2783-100)

17. $16 \%$ Formaldehyde (Pierce, catalog number: 28906)

18. $10 \%$ Glutaraldehyde (Electron Microscopy Services, catalog number: 16120)

19. Driselase powder (Sigma, catalog number: D8037)

20. Pectolyase Y-23 powder (Duchefa Biochemie, catalog number: P8004)

21. Anti-Tubulin antibody clone B-5-1-2 mouse (Sigma, catalog number: T5618)

22. Goat anti-mouse AlexaFluor 568 (Invitrogen, catalog number: A11004)

23. AlexaFluor 488-Phalloidin (Invitrogen, catalog number: A12379)

24. Normal goat serum (NGS) (Thermo Fisher, catalog number: 16210)

25. Triton X-100 (Sigma-Aldrich, catalog number: T8787)

26. Dimethyl sulfoxide (DMSO)

27. ProLong Diamond Antifade reagent, with or without DAPI (Invitrogen, with DAPI: P36962 or without DAPI P36961)

28. MilliQ Water

29. $30 \mathrm{mM}$ MBS (stock solution) (see Recipes)

30. Alexafluor 488-Phalloidin (stock solution) (see Recipes)

31. Anti-Tubulin antibody clone B-5-1-2 mouse (freezer stock solution) (see Recipes)

32. $2 x$ PHEM buffer (see Recipes)

33. 1X PHEM buffer (see Recipes)

34. 10x PBS (see Recipes)

35. $1 \times$ PBS (see Recipes)

36. $10 \%$ Triton $X-100$ (see Recipes)

37. Pre-fix solution (see Recipes)

38. Fix solution (see Recipes)

39. Enzyme solution (see Recipes)

40. Extraction solution (see Recipes)

41. Block solution (see Recipes)

42. Staining solution I (see Recipes) 
43. Staining solution II (see Recipes)

\section{Equipment}

1. Pipettes

2. Scalpel with blade \#11

3. Fine tweezers (Electron Microscopy Services, catalog number: 78138-01)

4. Tweezers

5. Water spray bottle

6. Orbital Shaker

7. Vacuum chamber (Bel Art, F42025) connected to vacuum pump or building vacuum

8. Speed Vacuum Concentrator

9. Microscope system equipped for illumination for Alexafluor 488 (GFP) and Alexafluor 568 (RFP/Texas Red)

Note: We recommend a point scanning confocal microscope, but other microscopes equipped with fluorescence are acceptable. Optional UV laser for DAPI if staining DNA using the ProLong Diamond Antifade with DAPI.

\section{Procedure}

1. Record plant genotype and which leaf is to be used. We usually use unexpanded leaf 4 of 1014-day plants to isolate its division zone part (Figure 1). Leaf 4 should be just emerging from the whorl.

Note: It is essential to consistently use the same leaf for comparisons. Juvenile vs. adult leaves have different morphological features (Freeling and Lane, 1994). Moreover, we have observed that stomatal division mutants will have different frequencies of abnormal divisions at each leaf, with the first (oldest) leaves having the greatest frequency of abnormal divisions and later (youngest) leaves having less frequent abnormal divisions. 
A

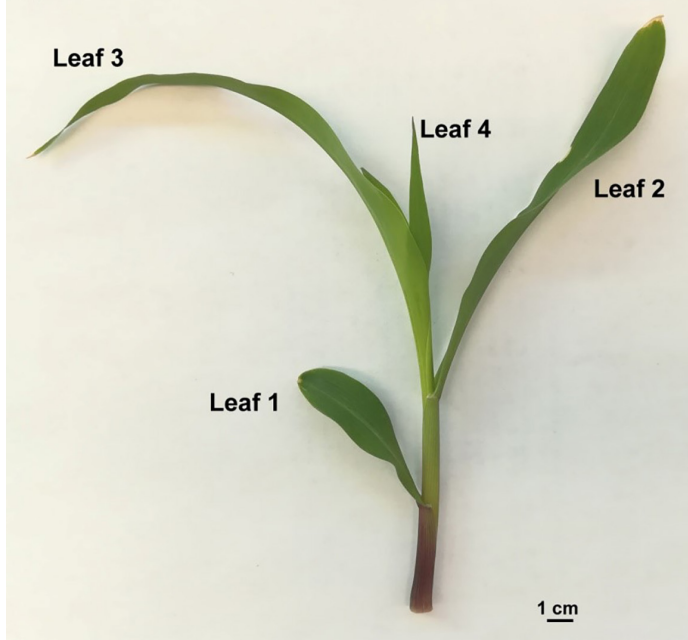

B

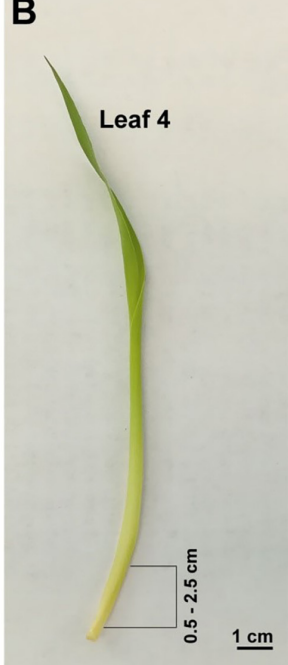

Figure 1. Maize seedling used for staining. A. The whole maize leaves after cutting from soil. B. The isolated leaf 4 , its base of $0.5-2.5 \mathrm{~cm}$ was indicated with black lines. Scale bar $=1 \mathrm{~cm}$.

2. Prepare fresh Pre-fix Solution (see Recipes).

3. Cut whole plant at the base of leaves from soil. Usually, we cut about $1 \mathrm{~cm}$ into the soil to make sure the division zone is included. Then, use a scalpel or razor blade to carefully peel away leaves 1-3. The leaves should be handled gently; using a scalpel instead of your hands to cut the leaves away one-by-one is most effective. Further details are given in Figure S1.

4. Dissect the division zone of leaf 4 (Figure 1B). Cut about $0.5-2.0 \mathrm{~cm}$ from the base of leaf 4 (Figure 1).

Important: If the ligule is more than $0.5 \mathrm{~cm}$ from where the leaf meets the stem, cell divisions will be complete and the leaf is too old.

5. Cut the tissue got from Step 4 into $1 \mathrm{~cm}$ long $\times 2-5 \mathrm{~mm}$ wide strips using a scalpel. Using fine tweezers, transfer slices to vial and fix for $30 \mathrm{~min}$ at room temperature, shaking in the dark.

Note: During cutting, put the tissues on a wet paper towel to keep its moist, and/or use a water spray bottle. Change scalpel blades every 2-3 plants as they become dull. Antibody staining works best at the edges of the tissues, so maximizing the perimeter area by cutting many thin slices is ideal.

6. Prepare Fix solution, $1 \mathrm{ml}$ per vial.

7. Remove Pre-fix solution with a pipette and add Fix solution. Place vials with caps removed or loose in a vacuum desiccator. Apply vacuum for $10 \mathrm{~min}$, then slowly release. Repeat 2 more times. Fix an additional $30 \mathrm{~min}$ at room temperature with gentle shaking.

Note: Tissue should sink during vacuum application.

8. Remove fix solution from scintillation vials and wash tissue with $1 x$ PHEM for $\sim 10$ min, 3 times. For the last wash, transfer tissue slices using fine tweezers to Netwell baskets wrapped in parafilm (Figure 2). Wrapping the bottom of the baskets in parafilm permits smaller wash and incubation volumes since it removes "dead" volume between the basket and the plate. 
Note: While care should be taken prior to fixation to avoid damaging or wounding the tissue, which will affect the cytoskeleton, now using the fine tweezers to make 3 or 4 very tiny holes in the fixed tissue will help the antibody gain access and improve the degree of microtubule labeling.

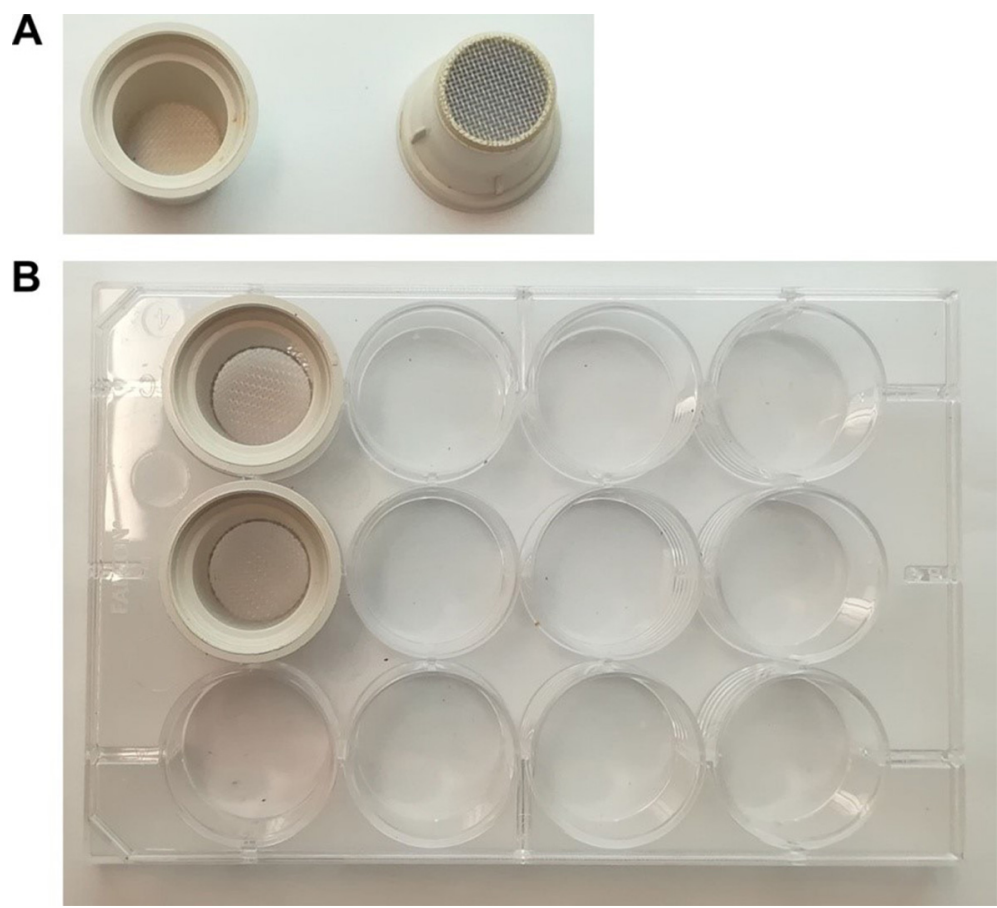

Figure 2. The image of Corning Netwell "immunobasket". A. The image of immunobasket's top and bottom side. B. The image of immunobaskets mounted on Falcon multiwell plate.

9. During the third wash, prepare fresh Enzyme Solution. After washing is complete, digest tissue with $500 \mu \mathrm{l}$, of enzyme mix per sample. Treat tissue for exactly 23 min-timing is critical. After this step, the tissue will be "sticky" and tend to adhere to itself.

Note: Make the enzyme solution fresh every time. After taking enzyme vials from fridge, do not open until they are warmed to room temperature (by touch) before opening to prevent condensation on enzymes (which will ruin them). Different manufacturer enzyme batches vary in activity so the precise incubation time may need to be optimized with each batch, usually between 15 and $25 \mathrm{~min}$.

10. Remove parafilm from baskets and wash tissue with $1 x$ PHEM for 10 min. Repeat 2 more times.

11. Wrap the basket in parafilm and incubate in Extraction Solution for $15 \mathrm{~min}$ (500 $\mu \mathrm{l}$ per sample).

12. Incubate in freshly made Blocking solution for $10 \mathrm{~min}$. Repeat two more times.

13. Remove blocking solution and wrap basket bottoms in fresh parafilm. Add 250-500 $\mu$ staining solution I, ensuring all tissue pieces are completely submerged. Apply vacuum to tissue for $10 \mathrm{~min}$ and then slowly release; repeat 2 more times. After infiltration, make again sure tissue is immersed. Wrap the tops of the baskets in parafilm as well to prevent evaporation. Incubate overnight, in the dark, with gentle shaking. 
Note: The solution is prepared as in Step 10, with antibody added as appropriate. Record antibody number, dilution, total volume, and incubation time.

\section{Next day:}

14. Remove parafilm from tops and bottoms of baskets and rinse 20 min in $1 x$ PBS with $0.05 \%$ Triton X-100. Repeat 2 times.

15. While the tissue is washing, determine the amount of AlexaFluor488-phalloidin needed for Step $11(10 \%$ of total volume needed. e.g., if making $500 \mu \mathrm{l}$ of Staining solution II, prepare $50 \mu \mathrm{l}$ of AF-phalloidin). Put the required amount of AF-phalloidin into speedvac and dry down into a pellet.

16. Prepare Staining Solution II, $0.5 \mathrm{ml}$ per sample.

17. Remove wash solution and wrap basket bottoms in parafilm, then add Staining Solution II. Apply vacuum as in Step 13. Incubate in the dark with gentle shaking for 3-4 $\mathrm{h}$ total (including $30 \mathrm{~min}$ vacuum) at room temperature. Record incubation time.

Note: Make sure tissue pieces are well covered!

18. Remove parafilm and wash $3 \times 10$ min in $1 \times$ PBS with $0.05 \%$ Triton-X 100 while shaking in the dark.

19. Mount in ProLong Diamond Antifade (with or without DAPI) and store at $4{ }^{\circ} \mathrm{C}$. If mounting with DAPI, tissues must incubate overnight before observation.

20. Observe using your microscope of choice. We recommend a point-scanning confocal microscope using a $60 x$ oil immersion objective.

In our case, Alexafluor 488, Alexafluor 568 and DAPI were excited at $488 \mathrm{~nm}, 568 \mathrm{~nm}$ and $405 \mathrm{~nm}$ respectively. $Z$ series were captured at $0.125 \mu \mathrm{m}$ intervals. A representative experiment data is shown in Figure 3.

Note: When observing, in order to avoid DAPI fluorescence bleeding into $488 \mathrm{~nm}$ channel, we usually set up to scan for AF568 and DAPI on one track, and 488 on a second track. 

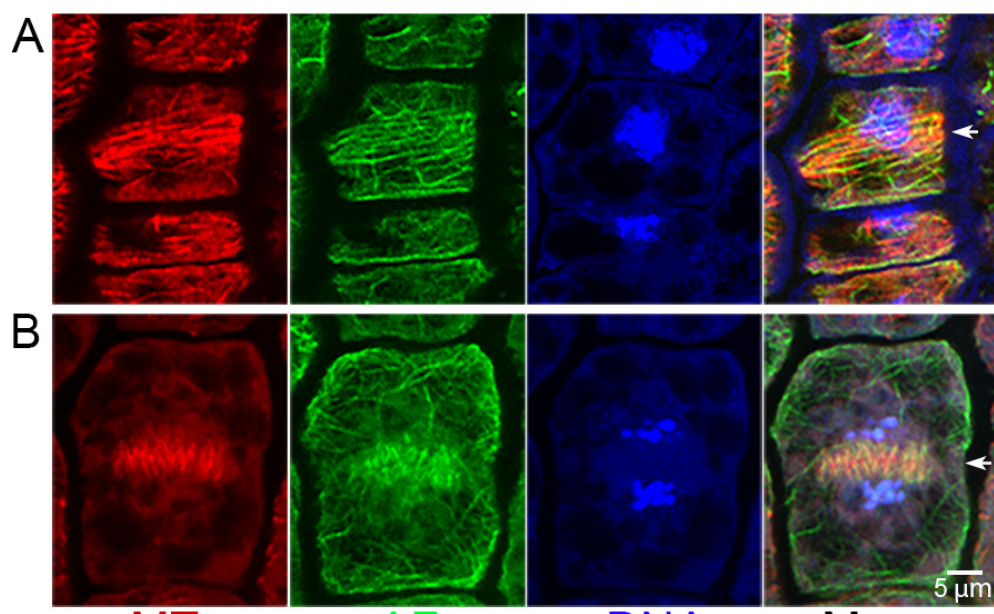

MTs

AFs

DNA

Merge

Figure 3. Microtubules, actin filaments and DNA visualized by double staining in maize

division zone. In each row, the first panel (red) shows microtubules, second panel (green) shows actin filaments, third panel (blue) shows DNA and final panel is a merge of the first three panels A. Late $G 2$ of a cell where the preprophase band is at the early stages of formation. White arrow indicates where the preprophase band is beginning to assemble. B. Telophase of a dividing cell, white arrow points to phragmoplast. Scale bar is shown in the bottom right panel; scale is identical in all panels.

\section{Recipes}

1. $30 \mathrm{mM}$ MBS (stock solution)

Add $106 \mu \mathrm{l}$ of DMSO per mg of MBS for $30 \mathrm{mM}$ solution

Note: MBS is labile in water, keep dry. Store stock solution tightly parafilmed in a secondary container with desiccant at $-20^{\circ} \mathrm{C}$.

2. Alexafluor 488-Phalloidin (stock solution)

a. AlexaFluor 488-Phalloidin (A12379) will arrive as a dry powder, resuspend in $1.5 \mathrm{ml}$ methanol

b. Store in the dark at $-20^{\circ} \mathrm{C}$

3. Anti-Tubulin antibody clone B-5-1-2 mouse (freezer stock solution)

Antibody Sigma T5618 is supplied at a concentration of $2 \mathrm{mg} / \mathrm{ml}$

We store all antibodies in our lab at $1 \mathrm{mg} / \mathrm{ml}$, and therefore add an equal volume 1x PBS to dilute the newly arrived antibody to $1 \mathrm{mg} / \mathrm{ml}$. The antibody is then divided into $50 \mu \mathrm{l}$ aliquots and each tube is parafilmed and stored in the dark at $-20{ }^{\circ} \mathrm{C}$ in a frost-free freezer. For a working stop, $50 \mu \mathrm{l}$ of glycerol is added to a tube to obtain a working solution of $0.5 \mathrm{mg} / \mathrm{ml}$. The working solution of antibody is stored at $-20^{\circ} \mathrm{C}$, and freeze-thaw cycles should be avoided

4. $2 x$ PHEM buffer $(500 \mathrm{ml})$

PIPES $18.14 \mathrm{~g}$

HEPES $6.5 \mathrm{~g}$ 
$\mathrm{MgSO}_{4} 0.99 \mathrm{~g}$

$25 \mathrm{ml}$ of $0.5 \mathrm{M}$ EGTA, pH 8.0

a. Dissolve in $400 \mathrm{ml}$ water, adjust the $\mathrm{pH}$ to 7.0 with $10 \mathrm{M} \mathrm{KOH}$ and bring volume up to $500 \mathrm{ml}$

b. Autoclave and store at room temperature for up to 6 months

c. EGTA will not dissolve at low pH therefore we find it easier to prepare using a pre-dissolved stock solution of EGTA

5. $1 \times$ PHEM buffer $(500 \mathrm{ml})$

$250 \mathrm{ml}$ 2X PHEM buffer

$250 \mathrm{ml}$ MilliQ water

6. $10 \times \mathrm{PBS}(1 \mathrm{~L})$

$\mathrm{Na}_{2} \mathrm{HPO}_{4} \cdot 7 \mathrm{H}_{2} \mathrm{O} 25.6 \mathrm{~g}$

$\mathrm{NaCl} 80 \mathrm{~g}$

$\mathrm{KCl} 2 \mathrm{~g}$

$\mathrm{KH}_{2} \mathrm{PO}_{4} 2.4 \mathrm{~g}$

Dissolve in $800 \mathrm{ml}$ of $\mathrm{H}_{2} \mathrm{O}$, adjust to $\mathrm{pH} 7.4$

Autoclave and store at room temperature for up to 6 months

7. $1 \times$ PBS $(500 \mathrm{ml})$

$50 \mathrm{ml} 10 \times \mathrm{PBS}$

$450 \mathrm{ml}$ MilliQ water

8. $10 \%$ Triton $X-100(10 \mathrm{ml})$

$1 \mathrm{ml}$ Triton X-100

$9 \mathrm{ml}$ MilliQ water

9. Pre-fix solution (1 ml)

Note: Prepare fresh.

$10 \mu \mathrm{l} 30 \mathrm{mM}$ MBS (final $300 \mu \mathrm{M}$ )

$10 \mu \mathrm{I}$ DMSO ( $1 \%$ added directly $+1 \%$ from MBS; final $2 \%$ )

$10 \mu \mathrm{l}$ 10\% Triton X-100 (final 0.05\%)

$0.5 \mathrm{ml} 2 \mathrm{x}$ PHEM buffer

$470 \mu \mathrm{l}$ MilliQ water

10. Fix solution $(1 \mathrm{ml})$

Note: Prepare fresh.

$10 \mu \mathrm{l} 30 \mathrm{mM}$ MBS (final $300 \mu \mathrm{M}$ )

$10 \mu \mathrm{l}$ 10\% Triton X-100 (final 0.05\%)

$10 \mu \mathrm{l}$ AlexaFluor 568-Phalloidin (final 1\%)

$250 \mu \mathrm{l} 16 \%$ formaldehyde (final $4 \%$ )

$75 \mu \mathrm{l} 10 \%$ Glutaraldehyde (final 0.75\%)

$0.5 \mathrm{ml} 2 \mathrm{x}$ PHEM buffer

$145 \mu \mathrm{l}$ MilliQ water 
11. Enzyme solution (1 ml)

Note: Prepare fresh.

$15 \mathrm{mg}$ Driselase powder (final 1.5\%)

$7.5 \mathrm{mg}$ Pectolyase $\mathrm{Y}$-23 powder (final $0.75 \%$ )

$500 \mu \mathrm{l} 2 \mathrm{x}$ PHEM buffer

$500 \mu \mathrm{l}$ MilliQ water

12. Extraction solution $(1 \mathrm{ml})$

$100 \mu \mathrm{l}$ 10\% Triton X-100 (final 1\%)

$50 \mu \mathrm{l}$ DMSO (final 5\%)

$0.5 \mathrm{ml} 2 \times$ PHEM buffer

$350 \mu \mathrm{l}$ MilliQ water

13. Block solution (1 ml)

$50 \mu \mathrm{l} 100 \%$ NGS (final 5\%)

$10 \mu \mathrm{l}$ 10\% Triton X-100 (final 0.05\%)

$500 \mu \mathrm{l} 2 \mathrm{x}$ PHEM buffer

$455 \mu \mathrm{l}$ MilliQ water

Note: NGS should be aliquoted into 1-2 $\mathrm{ml}$ tubes upon arrival to avoid freeze-thaw cycles.

14. Staining solution I (1 ml)

$50 \mu \mathrm{l} 100 \%$ NGS (final 5\%)

$0.5 \mu \mathrm{g} / \mathrm{ml}$ Tubulin antibody, 1x PBS

$100 \mu \mathrm{l} 10 \mathrm{x}$ PBS

$50 \mu \mathrm{l}$ 100\% NGS (final 5\%)

$1 \mu \mathrm{l} 0.5 \mathrm{mg} / \mathrm{ml}$ Tubulin antibody (final $0.5 \mu \mathrm{g} / \mathrm{ml}$ )

$850 \mu \mathrm{l}$ MilliQ water

15. Staining solution II $(500 \mu \mathrm{l})$

$50 \mu \mathrm{l}$ AlexaFluor 488-Phalloidin with methanol

Use speedvac to remove methanol from phalloidin and dry it into a pellet. Once the methanol has completely evaporated, resuspend the pellet with:

$50 \mu \mathrm{l} 10 \mathrm{x}$ PBS

$25 \mu \mathrm{l} \mathrm{100 \%} \mathrm{NGS} \mathrm{(final} \mathrm{5 \% )}$

$2.5 \mu \mathrm{l}$ Goat anti-mouse AF568

$422.5 \mu \mathrm{l}$ MilliQ water

\section{Acknowledgments}

This protocol was adapted from and optimized from previous methods (Panteris et al., 2006; Cartwright et al., 2009). MRF acknowledges funding from NSF-IOS 1754665. 


\section{References}

1. Cartwright, H. N., Humphries, J. A. and Smith, L. G. (2009). PAN1: a receptor-like protein that promotes polarization of an asymmetric cell division in maize. Science 323(5914): 649-651.

2. Facette, M. R., Shen, Z., Bjornsdottir, F. R., Briggs, S. P. and Smith, L. G. (2013). Parallel proteomic and phosphoproteomic analyses of successive stages of maize leaf development. Plant Cell 25(8): 2798-2812.

3. Facette, M. R., Park, Y., Sutimantanapi, D., Luo, A., Cartwright, H. N., Yang, B., Bennett, E. J., Sylvester, A. W. and Smith, L. G. (2015). The SCAR/WAVE complex polarizes PAN receptors and promotes division asymmetry in maize. Nat Plants 1: 14024.

4. Freeling, M. and Lane, B. (1994). The Maize Leaf. In: The Maize Handbook. Freeling, M. and Walbot, V. (Eds.). Springer Lab Manuals. Springer, New York, NY.

5. Hunter, C. T., Kirienko, D. H., Sylvester, A. W., Peter, G. F., McCarty, D. R. and Koch, K. E. (2012). Cellulose Synthase-Like D1 is integral to normal cell division, expansion, and leaf development in maize. Plant Physiol 158(2): 708-724.

6. Li, P., Ponnala, L., Gandotra, N., Wang, L., Si, Y., Tausta, S. L., Kebrom, T. H., Provart, N., Patel, R., Myers, C. R., Reidel, E. J., Turgeon, R., Liu, P., Sun, Q., Nelson, T. and Brutnell, T. P. (2010). The developmental dynamics of the maize leaf transcriptome. Nat Genet 42(12): 1060-1067.

7. Nelissen, H., Rymen, B., Jikumaru, Y., Demuynck, K., Van Lijsebettens, M., Kamiya, Y., Inze, D. and Beemster, G. T. (2012). A local maximum in gibberellin levels regulates maize leaf growth by spatial control of cell division. Curr Biol 22(13): 1183-1187.

8. Panteris, E., Apostolakos, P. and Galatis, B. (2006). Cytoskeletal asymmetry in Zea mays subsidiary cell mother cells: a monopolar prophase microtubule half-spindle anchors the nucleus to its polar position. Cell Motil Cytoskeleton 63(11): 696-709.

9. Raissig, M. T., Abrash, E., Bettadapur, A., Vogel, J. P. and Bergmann, D. C. (2016). Grasses use an alternatively wired bHLH transcription factor network to establish stomatal identity. Proc Natl Acad Sci U S A 113(29): 8326-8331.

10. Rasmussen, C.G. (2016). Using live-cell markers in maize to analyze cell division orientation and timing. In: Plant Cell Division. pp. 209-225. Humana Press, New York, NY.

11. Sylvester, A. W., Smith, L. and Freeling, M. (1996). Acquisition of identity in the developing leaf. Annu Rev Cell Dev Biol 12: 257-304.

12. Wu, Z., Chen, L., Yu, Q., Zhou, W., Gou, X., Li, J. and Hou, S. (2019). Multiple transcriptional factors control stomata development in rice. New Phytol Doi: 10.1111/nph.15766. 